\title{
Kirkestormen, neo-Gnosticism and Secular Christianity
}

\author{
Professor MA, BD, PhD, DD George Pattison
}

Abstract: The article notes that Kierkegaard's writings on the Church had a considerable impact on theology in the $20^{\text {th }}$ century including, not least, the theological movement sometimes referred to as 'religionless' or 'secular' Christianity. Like that movement, Kierkegaard problematized the very idea of a Church. However, his writings also reflect a rejection of life in the world rather than the 'secular' affirmation of thisworldliness. This can seem like a version of Neo-Gnosticism. However, it is argued that Kierkegaard's rejection of the world is neither to be understood in the perspective of the Augustinian doctrine of original sin nor of Gnostic dualism but reflects a modern understanding of the world as a unitary whole. The question then is whether such a world is favourable to human flourishing.

\section{Kierkegaard's Legacy to Ecclesiology}

There is room for debate as to whether Søren Kierkegaard was in any usual sense a Protestant 'theologian'. As we know, he never held either an academic or an ecclesiastical position, although he did consider the possibility of lecturing at the Pastoral Seminary as well as that of retreating to a rural parish after the completion of his pseudonymous authorship. Furthermore, despite the fact that his books have regularly appeared on the reading lists of theology courses, they were not written for the purpose of servicing academic theology and might even be read as an all-out assault on the very possibility of such a thing. Nevertheless, it is clear that he thought and wrote from within a perspective very largely determined by the heritage of the Reformation, in particular by the form which that heritage took in Danish Lutheranism. This general context was further focussed by the powerful influence from the Pietist spirituality that he was exposed to through his family's attendance at the meeting house at Stormgade and by his studies in the theological faculty at Copenhagen University. And, if his books were not written to serve the purposes of academic theology, they undoubtedly addressed issues that were of cen- 
tral concern to ecclesiastical and academic theologians of his time, such as H. L. Martensen and, increasingly in his later years, they directly addressed the question of the Reformation heritage and its significance for Christian life and thought. Paradoxical as it might seem (and as was also the case with his pseudonymous works), Kierkegaard's arguments would become central to $20^{\text {th }}$ century theological debates about the nature of the Church and its relation to society and, especially, to modern society. Although repeatedly insisting that he was 'without authority', that his task was merely the Socratic task of raising the question as to the true definition of Christianity, and that he was definitely not a reformer, Kierkegaard would come to be cited as if he was a founding father of a new reformation. In this regard, the thrust of his work would seem to suggest a resounding 'Yes' to Peter Widmann's question 'War die Reformation also eher eine Deformation, ja, die Mutter der meisten Deformationen des Christlichen in der Moderne?' Moreover, in terms of his $20^{\text {th }}$ century reputation, Kierkegaard's view was not treated as one opinion amongst others, but acquired something like a normative status.

Albert Bärthold, one of the earliest translators of Kierkegaard into German, could already conclude his 1884 pamphlet Was Christentum Ist, with the following words: 'Diese Darstellung folgt im wesentlichen S. Kierkegaard's Ausführungen', even though-as he acknowledges - he has not specifically cited Kierkegaard in the text. The following year, Bärthold published a further pamphlet Die Wendung zur Wahrheit in der modernen Kulturentwicklung, prompted by the critical reception of Was Christentum Ist in the Leipziger theologische Litteratur-Blatt. Here he makes clear that despite the tendency of those he refers to as followers of H. L. Martensen to pass over Kierkegaard in silence, it is the latter who has the greater insight and indeed a decisive insight into the situation of Christianity in modern culture. This situation, he suggests, is essentially the same as in the time when Boniface took his axe to Odin's oak: the indifference with which this was greeted by the Hessians merely indicated that Odin's religion had long since ceased to be a vital force in their lives. So today: if there no longer seems to be any great controversy in the relations between Christianity and society this is because there is now a general consensus that 'das überlieferte Christentum paßt nicht zu der modernen Kultur. Die leidenschaftliche Erregung im Durchkämpfen dieser Überzeugung ist vorbei, mit Angriffen auf das Christentum ist nicht mehr viel Ruhm zu gewinnen trotz aller Anstrengung, auch die Vermittlungsversuche zwischen Kultur und Christen- 
tum erregen keine Interesse mehr'. ${ }^{1}$ In this situation it is Kierkegaard and not Martensen or Ritschl from whom authentic Christian theology can learn most.

Bärthold, we may say, was a more or less obscure pastor (in Halberstadt), but within 50 years his judgment had become widely accepted amongst theologians, especially, of course, those who were associated with dialectical theology. The title given to one of the early anthologies of Kierkegaard's journals by another pioneering translator, Herman Gottsched, Das Buch des Richters (1905), is fairly indicative of the kind of status that he was acquiring early in the $20^{\text {th }}$ century (SK had himself noted that 'If after my death they publish my journals, they could do so under the title: The Book of the Judge', ${ }^{2}$ but Gottsched is perhaps the only translator actually to have done so). The implication is that Kierkegaard himself is no mere critic or even (to use his own term, 'corrective') but the 'judge' whose life and work are a judgment on the state of contemporary Christianity. This may seem an extraordinarily conceited claim, when made by Kierkegaard himself-but in the light of his 20th century reception it seems merely to have been realistic.

By 1950, the British Methodist theologian H. V. Martin could write that

One of the outstanding features of the movement of Christian thought during the last quarter of a century has been the remarkable interest shown in the work of that lonely thinker of Denmark, Søren Kierkegaard. Though he died nearly a century ago, his influence did not spread widely until after the First World War. Then, through the writings of Barth and other leaders of the revolt against the prevailing Liberal Theology the name of Kierkegaard became known as that of possibly the greatest force behind this new theological movement. ${ }^{3}$

Martin is not a particularly well known figure, but that precisely underlines the point as regards the status Kierkegaard had acquired by the mid-twentieth century, i.e., that he was no longer the preserve of specialist commentators or theological extremists but had achieved something like normative status. Through the 1950s and 1960s, however, this would be especially true amongst those who developed the more radically anti-ecclesiastical implications of Barth's early

1. Albert Bärthold, Die Wendung zur Wahrheit in der modernen Kulturentwicklung (Gütersloh, Bertelsmann 1885), 8.

2. Søren Kierkegaard, Søren Kierkegaards Skrifter (Copenhagen: Gad 2003), 335 (journal entry NB 10: 158).

3. H. V. Martin, The Wings of Faith (London: Lutterworth Press 1950), 7. 
thought and who, through a certain reading of Bonhoeffer's prison writings, were developing a religionless or secular Christianity.

Kierkegaard did not perhaps entirely fit with all aspects of the secular theology agenda, but he was undoubtedly a seminal figure in its rise and subsequent formation. Now it is clear that the development of the relations between Church (or, more generally, religion) and society has not followed the path predicted by the secular theologians. Within theology itself secular theology and religionless Christianity have more or less vanished from the scene. Yet the question as to the significance of the secular within religion and theology has surely not been decided once and for all, and simply to repeat the mantra that we are now in a post-secular situation is enormously to oversimplify-a trap into which Charles Taylor for one has not fallen. The particular form that the secular Christianity of the 1960s took is, inevitably, tied to cultural and other factors specific to that time, but although much of its agenda is no longer directly relevant it has left some unfinished business and poses a provocation to contemporary theology to reflect more critically on its own place, its own responsibility, and its own future in the contemporary situation. The aim of this paper is merely to explore some aspects of Kierkegaard's contribution to such a ressourcement. The outcome will be problematic, but that is perhaps as it should be!

\section{Kierkegaard and Secular Theology}

Let me immediately state what I see as Kierkegaard's key contribution to secular theology in the form that it took fifty years ago. Firstly, Kierkegaard problematized the identification of the Church as a legitimate historic manifestation of Christianity. Of course, previous reformers and reforming movements had problematized particular forms of the Church, but these had normally been for the sake of recalling the Church to some earlier state. Now it might seem possible to read Kierkegaard's repeated use of the expression 'New Testament Christianity' as implying just that, as if the point was to recall the historically degenerated Church back to the purity of the apostolic era. However, without denying that something like that idea is in play in some of his writings on the Church, some of them seem to point to a still more extreme solution: that 'the individual' seeking God is ultimately alone with Christ and that the nature of the Christ-relationship is ultimately outside all external mediation. Let me cite Bruce Kirmmse: 
... Kierkegaard did not simply go back to the fourth century and reject Constantine and the idea of a State Church. Toward the end of his life it also becomes undeniably clear that Kierkegaard rejected 'the notion of the congregation' as such ... The problem began not with the 1849 constitution, nor with Mynster, nor the Reformation, the Middle Ages, or even in the fourth century, but much earlier, with the foundation of the Church by Peter and the other apostles and the baptism of the three thousand on the first Pentecost ... ${ }^{4}$

And Kirmmse goes on to quote a well-known passage form Kierkegaard's 1854 journals entitled 'An alarming note', which begins 'Those three thousand who were added to the congregation en masse on Pentecost - isn't there fraud here, right at the very beginning? Ought not the apostles have been uneasy about whether it was really right to have people become Christians by the thousands, all at once?'. 5 (This passage, incidentally, is all the more remarkable given Kierkegaard's frequent discussions of apostolic authority as having been above question and as sharing in the paradoxical determinants of the Incarnation itself: here, however, not even the apostles are spared his critical gaze.)

The point, then, is that in his later writings on the Church, Kierkegaard puts the very idea of a Church as such up for question to the extent that what he effectively asks is, simply: Does Christianity actually need a Church? And note, the crucial and distinctive element here is Christianity. From the Enlightenment onwards there has been a steady stream of critics attacking both the reality and the idea of the Church or of any 'positive' religion that sought immunity from scrutiny by reason. The absurdities of theology, the machinations of priestcraft, and the historical unreliability of the scriptures were compounded in a single ensemble that was to be rejected wholesale. Although a certain ethical Jesus was sometimes spared the otherwise universal condemnation, the point was to get rid of both Christianity and the Church. However, as Kirmmse for one goes on to make clear, whilst Kierkegaard became radically anti-ecclesiastical, he did so precisely for Christian reasons: 'we must insist on the whole Kierkegaard, radical and uncut: Christian and anti-clerical ... We must agree with the churchly Kierkegaard interpreters about the absolute centrality of Kierkegaard's Christianity. And we must agree with the freethinkers that he was, in the end, radically anti-Church'. ${ }^{6}$

4. B. Kirmmse, " "But I am almost never understood ..” Or, Who Killed Søren Kierkegaard' in The Self in Society, eds. G. Pattison and S. Shakespeare (Basingstoke: Macmillan 1998), 187.

5. Kirmmse (1998), 187.

6. Kirmmse (1998), 190. 
This, then, is probably Kierkegaard's most significant legacy to religionless and secular Christianity: the idea-perhaps the mere possibility of envisaging - a kind of Christianity that was able to dispense with the Church but to do so for quite different reasons and with quite different outcomes from the transformation of Christianity and the Church into one or other variant of a 'merely' human ethical community. Ronald Gregor Smith was one of the leading British proponents of religionless Christianity, a translator of both Bonhoeffer and Kierkegaard, as well as commissioning editor of the SCM Press that was strongly associated with many of the radical theological movements of the period after World War II-and he was clear about the nature of Christianity. As he wrote in the Introduction to The Last Years, a selection of Kierkegaard's journal entries from 1853 through to 1855 , 'we face here a challenge to all the traditional forms of "Christianity", Protestant and Catholic and even sectarian. For however strong the pietist influence upon Kierkegaard ... it is neither here nor in any other specific form of the Christian tradition that we can finally classify Kierkegaard. Rather, we have to regard his challenge as directed against all traditional forms ... the old Reformation is over. We face now an unprecedented situation in Christendom'. ${ }^{7}$

But - and this is less generally noticed-Kierkegaard also provided the secular theologians with a new model of theological writing. Neither priest nor professor, Kierkegaard pursued the central questions of Christian theology outside the Church and outside the academy, simply as an author. I have already indicated that he was, of course, theologically well-educated and the theology he was educated in was both ecclesiastical and academic. Yet, as an author, he operated in the market-place of what he so frequently called the 'market-town' of Copenhagen, where, as he so frequently lamented, market forces did not secure a good or widespread reception if his work and, had he not had the support of a private income, the achievement of his authorship might not have been possible. (Various studies suggest that Kierkegaard is not entirely to be trusted in this view of things, and whilst it is true that some of his books did have very poor sales, the authorship was, on the whole, a profitable venture-and it was Kierkegaard himself who long resisted Reitzel's urging to print a second edition of Either/Or.) Now we may - and many commentators docast a somewhat-what? envious? condescending? malicious?- - smile in the direction of S. A. K., the pampered and self-indulgent man of

7. Ronald Gregor Smith, 'Introduction' in Søren Kierkegaard, The Last Years: Journals 1853-55 (London: Collins, 1965), 15. 
letters absorbed in the twists and turns of his self-centred literary labyrinth, but we should not underestimate the importance of the move whereby he made the subject-matter of Christian theology the subject-matter of an authorship carried out under secular premisses. In relation to this move, the question as to whether it was selffinanced or commercially successful is purely secondary.

In this regard, the persistent biographical interest in Kierkegaard is not without its significance, since, as Kierkegaard himself many times said, a religious teacher is great not so much by virtue of what he says as with regard to what he does. Thus, Kierkegaard himself became portrayed as the solitary hero of an absurd faith who threw himself against the twin establishment of the Hegelian system and the Church. Kierkegaard the man became integral to the image of Kierkegaard the author who, in turn, was integral to Kierkegaard the critic of Christendom.

\section{Kierkegaard and Neo-Gnosticism}

However, Kierkegaard was not an unproblematic source for the secular and religionless theologies of the 1960s. The familiar biographical story itself gives some clues as to why this should be so, since the episode with Regine seemed to be rooted in a psycho-sexual scenario that had become very alien to a post-Freudian generation for which sexual fulfilment was regarded as a normal and necessary part of adult life. Whereas Victorians might have had some sympathy for a religious conscience afflicted with anxieties about sexuality, such anxieties were being increasingly seen by the 1960s as signs of pathology. In that the 'actions' of Kierkegaard's life could, in the standard hagiographies, come to be condensed into 'the broken engagement', the 'Corsair affair', and the 'Attack on Christendom', it seems not difficult to see him as exemplifying a kind of hostility to the world that, beginning with the rejection of sexuality, proceeds through the rejection of contemporary social values, and ends with the rejection of any possibility of a holy community on earth. Seen in this perspective, the attack on the Church is simply a further unfolding of the logic implicit in the story of the broken engagement: that the love of God is not compatible with human fulfilment in the time of this earthly life. This is what the inclusion of the term 'neo-Gnosticism' in the title of my paper points to. Of course, we do not find anything in $\mathrm{Ki}$ erkegaard corresponding to the complex and arcane hierarchies and theogonies of Gnostic speculation, but we do seem to find a reversion to a kind of denial of the body and an apparent urge to flee the 
life of this world that had at most been muted in mainstream Christianity for many centuries previously.

Ronald Gregor Smith says of Kierkegaard's life that 'It is a tragic story, and the tone of the last words he wrote ... is profoundly disturbing ...'8 Smith refers here to the entry that, in his translation reads

The definition of this life is to be brought to the highest degree of disgust with life. He who is brought to this point and can then hold fast, or he whom God helps to hold fast, that it is God who has brought him to this point - he it is who from the Christian standpoint has passed the examination of life, and is ripe for eternity. Through a crime I came into existence, I came into existence against God's will. The fault, which in one sense is not mine, even if it makes me a criminal in God's eyes, is to give life. The punishment fits the fault: it is to be deprived of all joy of life, to be brought to the supreme degree of disgust with life ... And what pleases [God] even more than the praise of angels is a man, who in the last lap of his this life, when God is transformed as though into sheer cruelty, and with the cruellest imaginable cruelty does everything to deprive him of all joy in life, a man who continues to believe that God is love and that it is from love that God does this. Such a man becomes an angel. And in heaven he can surely praise God'.?

This, it could be said, sounds more Schopenhauerian than Christian, and it is perhaps not coincidental that Kierkegaard began reading Schopenhauer in 1854, whereafter the element of all-embracing world-pessimism becomes markedly more pronounced in his writings. As all readers of Kierkegaard know, such pessimism had many antecedents in earlier works and earlier journal entries: however, the tendency to dualism now seems to be reified and worldly life as such becomes categorized as inherently and essentially opposed to God.

The connection made in this passage between biological procreation and disgust with life-pathological, in a post-Freudian perspective-is also witnessed in the published writings of the Kirkestorm itself where Kierkegaard's attacks on baptism, confirmation, and marriage go beyond the kind of insistence on baptism requiring responsible assent on the part of the one to be baptized.

Baptism is a decisive point. In the $7^{\text {th }}$ number of The Instant, Kierkegaard wrote

The Christianity of "Christendom" sees that everything depends upon establishing the maxim that one becomes a Christian as a child, that if one is rightly to become a Christian, one must be such from infancy.

8. Kierkegaard (1965), 19.

9. Kierkegaard (1965), 367-8. 
This is the basic falsehood. If this is put through, then good-night to the Christianity of the New Testament! Then "Christendom" has won the game-a victory which is most fitly celebrated by a regular gorge of meats and drinks, a wild carouse with bacchants and bacchantes (priests and midwives) at the head of the procession. ${ }^{10}$

The mention of midwives is significant here, since it flags up that for Kierkegaard the issue is not that an infant is unable to give informed consent, but that Christendom conflates biological birth with Christian rebirth. Later in the same number he will say that 'everyone that is born is by being born a lost soul', which might seem to coincide with the reasoning of Augustinian Christianity that infant baptism is needed precisely because we are each of us conceived and born in sin. However, Kierkegaard's point is subtly different and he immediately goes on to make a link to Paul's stated recommendation of the single state: by not marrying (that is, by not procreating) we refrain from putting a new soul in danger and we refrain from augmenting the sufferings of Christ that are needed for rescuing souls from mortal danger. As Kierkegaard puts it

Surely it was the least one could require of a man who was himself saved and redeemed at so dear a price that it was accomplished by another man's agonizing life and death, it was after all the least one could require that he should not engage in begetting children, in producing more lost souls, for of them there are really enough. By the propagation of the race the lost are poured out as from a cornucopia. And should then the man who is saved, as though in thanksgiving for his salvation, also take part in the propagation of the race, making his contribution to the number of the lost?11

In the following article, 'Confirmation and the Wedding', Kierkegaard proceeds to one of his sharpest attacks on Christendom, seemingly interpreting Paul's recommendation of the single state as a definitive statement of God's own will and deducing that Christian marriage is therefore a contradiction in terms and is, in fact, a means of transforming Christianity 'into the exact opposite' of what it is.

The Christianity of the priests ... is directed to cementing families more and more egoistically together, and to arranging family festivities, beautiful, splendid family festivities, e.g. infant baptism and confirmation,

10. Søren Kierkegaard, Søren Kierkegaards Skrifter 13 (Copenhagen: Gad, 2009), 295 (translation from S. Kierkegaard, tr. W. Lowrie, Attack upon "Christendom", tr. W. Lowrie (Princeton: Princeton University Press, 1968), p. 212.

11. Kierkegaard (2009), 296; Kierkegaard (1968), 214. 
which festivities, compared for example with excursions in the Deer Park and other family frolics, have a peculiar enchantment for the fact that they are "also" religious. "Woe unto you," says Christ to the "lawyers" (the interpreters of Scripture), "for ye took away the keys of knowledge, ye entered not in yourselves, and them that were entering in ye hindered. This is the highly respected profession of the priests, a way of livelihood which prevents men from entering the kingdom of heaven. ${ }^{12}$

This could be read as a radical development of the Augustinian-Reformation view of original sin, although (obviously) it goes much further than the characteristic Lutheran and Calvinist applications of this doctrine and seems to tend more to a kind of post-Christian position similar to that of Schopenhauer, where existence or life is as such a crime and, moreover, a state of continuous and unrelieved suffering in which there is no trace of divine goodness, mercy or love. Kierkegaard-as opposed to Schopenhauer-still, as that poignant final journal entry makes clear, does believe that faith can nevertheless see that God is love and that all the suffering which the soul endures in this life is itself a trial of love. However, in believing this the sufferer has no evidence to back up his claim. The world looks, as Schopenhauer said it was, like a giant torture chamber in which we can choose only to be tortured or torturers (or presumably, in the case of Kierkegaardian self-tormentors, both).

It is striking that it is in this very last period of his life that Kierkegaard did begin reading Schopenhauer, in May 1854, according to Niels-Jørgen Cappelørn, who sums up the impact of this reading as resulting in the appearance or intensification of such emphases as the necessarily voluntary nature of Christian suffering, the need for suffering as a reduplication of ethical and religious ideals and for asceticism as a consequence of recognizing the wretchedness of life, and a view of contemporary Protestantism as essentially marked by eudaemonism. At the same time, he also sees Kierkegaard as noting that a certain kind of misanthropic pessimism (such as that of Schopenhauer himself) can itself be "a new and sophistic form of eudaemonism or even of a pleasure characterized by melancholy or spleen", where it remains merely theoretical and is not accompanied by ascetic renunciation. ${ }^{13}$

Awareness of an albeit qualified affinity with Schopenhauer is important because what is going on here in Kierkegaard's text is some-

12. Kierkegaard (2009), 305; Kierkegaard (1968), 222.

13. See N.-J. Cappelørn, "Historical Introduction: When and Why did Kierkegaard begin Reading Schopenhauer" in Schopenhauer-Kierkegaard: Kierkegaard Monograph Series, ed. L. Hühn (Berlin: de Gruyter), forthcoming. 
thing different from a radical application of the doctrine of original sin. Fully to defend what I am about to say would demand too great a digression at this point, since it would demand an extensive interpretation of one of Kierkegaards's more complex pseudonymous works, The Concept of Anxiety, but I believe that the discussion of original sin in that work effectively amounts to a systematic demolition of the Augustinian view. ${ }^{14}$ It is not only that Kierkegaard-albeit in a very different key from a Kantian or Hegelian interpreterportrays the biblical account of the Fall as an archetypal narrative of how each of us becomes what we are rather than as an historical narrative that explains human origins. It is also that the Fall, effected uniquely in each single human life, is not a result of procreation but occurs, through anxiety, when freedom succumbs to the vertigo brought on by its own infinite possibilities and thereupon falls into finitude. In other words, even though (as he goes on to argue) there may be a quantitative accumulation of sin from one generation to another, each individual who falls ultimately does so in and through their own free act or, to be more precise, their failure to enact the possibilities they have for free self-responsibility. Even if all actual human beings are fallen, each falls by him- or herself.

But how does this square with the assertion we have heard in The Instant that a soul is lost simply by virtue of being born and by Kierkegaard's disgust at procreation and family life? The question directs us to some of the central issues in Kierkegaard's overall theological orientation and, I shall suggest, leads us to key aspects both of his fundamental modernity and of his final lapse into pessimism.

Whilst not ruling out a residual logical tension on this point, I should like to suggest something like the following. Even when, as in Barth, the Reformation tradition asserts that the image of God in human beings was completely annihilated in the Fall so that no 'point of contact' with the divine remains and no earthly ordinances retain even a trace of God's original good ordering human life, the total depravity of human beings nevertheless stands within a narrative in which the memory of paradise lost and the anticipation of paradise regained are integral and essential moments. Each Christian is, then, in a sense simultaneously a member of two (arguably even three) kingdoms, the world's and God's. 'The world', i.e., the fallen world, is not the sole horizon within which human life is to be experienced and interpreted.

14. In support of this view, see N.-J. Cappelørn, "The Interpretation of Hereditary Sin in The Concept of Anxiety by Kierkegaard's Pseudonym Vigilius Haufniensis" in Tijdschrift for Filosofie, 72 (2010), 131-46. 
By way of contrast, Kierkegaard's rejection of the doctrine of original sin is premissed on the assumption that there is only one world. This is the world that he most eloquently figures in the discourses on the lilies and the birds, discourses where we see Kierkegaard at his most world-affirming, insisting on the goodness of creation and the goodness of life simply as such. The problem with human beings is not that they have lost all possibility of associating with God and still less that they have dragged down the rest of creation with them. The problem with human beings is that they do not take advantage of the freedom they have, here and now, to be like the lilies and the birds and to give thanks for their existence as a good and perfect gift of God. As he writes in one of these discourses:

\begin{abstract}
So, the fact that you came into the world, that you exist, that 'today' you have got what you need in order to exist, that you came into the world, that you became a human being, that you can see-just reflect on the fact that you can see-that you can hear, that you can smell, that you can taste, that you can feel, that the sun shines on you and shines for you and, when you grow weary, the moon comes up and the stars are lit; that winter comes and all of nature changes its garb and takes on a strange new role - and does so to please you; that spring comes and the birds return in numerous flocks - and do so to give you joy; that the green shoots spring up, the woods grow beautiful and present themselves as a bride-and do so to give you joy ... is this nothing to be joyful about? ${ }^{15}$
\end{abstract}

Here, now, we can turn to God, we can become like the lilies and the birds, 'the world' can become God's good creation.

Here, we may say (and the motif of absolute dependence in these discourses might confirm the point), Kierkegaard is operating within a Schleiermacherian or more generally modern view of the world as a unitary whole. In relation to the reality of this world, there is no other world, no lost 'fantastic' paradise in the past, and no utopistic paradise in the historical future. Thus the religious challenge is not so much how to get out of the world but how we are and how we are to be in it. It is a question of how we see and how we experience the world and how we choose to live our lives in it. In this situation we are faced with a very basic choice between world acceptance and world affirmation on the one hand and world rejection and world denial on the other. Kierkegaard has often been compared with Ni-

15. Søren Kierkegaard, Søren Kierkegaards Skrifter 11 (Copenhagen: Gad 2006), 43-4; (translation from S. Kierkegaard, Kierkegaard's Spiritual Writings, tr. G. Pattison (New York: Harper Perennial 2010), 215-6. 
etzsche, but here the analogy also encompasses a strong disanalogy. On his own account, Nietzsche's liberation from Schopenhauerian pessimism was not so much a matter of acquiring a different understanding of the world but of learning to value it differently and of saying Yes where Schopenhauer, his educator, had said No. Kierkegaard's way, we might say, was in a sense, the opposite-from the world-affirmation of the lilies and the birds to the world-denial of the final journal entry and the attack on Christendom. Yet it is not simple world-denial, and even in the extremity of the final journal entry, Kierkegaard sees this world and how we are in this world as decisive with regard to our God-relationship. The suffering we endure, the disgust we experience in the face of life, is not to be subdued or overcome but lived to the full in the faith that it is an expression of God's love. ${ }^{16}$ This is not, contra the charge of neo-Gnosticism, a matter of fleeing the world but a matter of how we are in it. Kierkegaard is both Schopenhauer and Nietzsche, and neither. Thus, to come to the point, when there is only one world and religious existence is a matter not of holding to a particular set of doctrinal positions but of how we are in our lives in that one world, then the move from one extreme to another, from world affirmation to world denial or from world denial to world affirmation, is easier, more rapid, and more dependent on the contingencies of individual life and experience than when (as in the traditional Christian view) human life is always interpreted doctrinally in the perspective of two worlds simultaneously. Thus, Kierkegaard's slide into extreme dualism and extreme pessimism is, paradoxically, a result of his anti-Augustinian insistence on the world of human life and experience as a single world, bounded only by divine transcendence. If it is a kind of 'neo-Gnosticism', its modernity is at least as important as its echoes of ancient dualisms, since it has renounced any possibility of there being any other world than this. In this sense, Kierkegaard's 'world' is essentially the same world that a Feuerbach, a Marx, or a Nietzsche would have recognized as their own. And if that had not been so, it is hard to imagine Kierkegaard finding the same response amongst $20^{\text {th }}$ century readers that he did in fact find, and not least amongst readers who were also readers of Feuerbach, Marx, and Nietzsche.

16. Perhaps the closest analogy here is neither Schopenhauer nor Nietzsche but Simone Weil, with particular regard to the interplay of themes of affliction, attention and the love of God in her work. 


\section{Conclusion}

We might seem to have digressed a long way from the question of the reformation and the deformation of the Church. However, our journey has, I think, illustrated why Kierkegaard's attack on the deformation of the Church in contemporary Danish Lutheranism does not and cannot be for the sake of reinstating some earlier phase of Church history, whether that is the monastic heroism of the Middle Ages or the purity of the apostolic Church. Kierkegaard's challenge-implicit already in Philosophical Fragments - is to each individual to become a contemporary of Christ outside of or beyond ecclesiastical mediation. Whether we see good in all things or are disgusted by all things, that means receiving our lives-as do the lilies and the birds - direct from God's hand as a good and perfect gift, a gift of love. Of course, there is more work to do here in terms of spelling out how this theme is further developed by Kierkegaard in terms of the interplay of his theology of creation and his theology of redemption. However, I hope to have gone some way to showing how Kierkegaard's attack on Christendom could appropriately inaugurate a movement towards what would come to be known as religionless or secular Christianity despite what, at first reading, might look like its extremely dualistic other-worldliness. In this regard we may say of the pathological dimension of Kierkegaard's witness something like what he himself said of the role of the miraculous in the life of Christ - that it serves to attract attention, but it is not itself what is to be believed or be attended to. Kierkegaard's own private version of the common sickness unto death may arouse our interest, but it is not itself interesting and nor, crucially, should it finally deflect our attention from or give us an excuse for evading the challenge of his Attack. That challenge is simply whether the idea of 'Church' remains relevant to configuring faithful models of Christian existence in the situation of modernity.

Putting it like this does not, I think, presuppose that we must agree with Kierkegaard, but it does mean that we take seriously his view that the idea and the witness of the Church are, at best, problematic, uncertain, ambiguous, and endlessly challengeable. No single reformation will ever put it right, but if reformation could be understood in the sign of Kierkegaardian repetition, we might make a start at living in what Ronald Gregor Smith called the unprecedented situation of Christendom today. 